\title{
The Educational Thinking of Hasyim Asy'ari about Student Ethics Against to the Teachers in the Digital Era
}

\author{
Supriyanto ${ }^{1}$, Elly Malihah ${ }^{2}$, Helius Sjamsudin ${ }^{3}$, and Erlina Wiyanarti ${ }^{4}$ \\ \{supriyanto@student.upi.edu ${ }^{1}$ \} \\ University Education Indonesian ${ }^{1,2,3,4}$
}

\begin{abstract}
This article is the result of a study of various literatures, with the aim of analyzing and describing Hasyim Asy'ari's educational thoughts about student ethics towards teachers in the digital era. The results of this study can be explained ethics of students in demanding knowledge from the point of view of Hasyim Asy'ari and the reality of the behavior of students that most students in the digital age have not carried out their obligations as students to study seriously, they are more engrossed in their world, namely playing with friends, playing gadged and the internet. Even though this is the reality, there are still students who really learn seriously, excel and are able to compete. The educational thinking of Hasyim Asy'ari is very well applied in this every learning of digital era. This is in line with one of the goals of national education, which is forming noble students. In the context of learning, teachers can educate students in the digital era is to utilize the advances in technology, by utilizing social media to interact and instill ethics for students.
\end{abstract}

Keywords: Hasyim Asy'ari education thoughts, student ethics, digital era.

\section{Preliminary}

Basically, every human being since childhood has good ethics and is always taught to have good ethics by both parents and certainly all hope that every human being has good ethics. But what happens to every human being is not as expected. As is known that every human being has different characters, born in different environments, educated in different ways, associating with different ethic friends, and coupled with the development of increasingly sophisticated science and technology, which demands every human being to follow its development.

Every generation will be faced with the development of different sciences and technologies and certainly the young generation today is different from the previous generation. Today's generation was born in the age of advancement in information technology that developed very quickly. Like gadget, the internet and various other facilities based on applications cannot be separated from the hands of the current generation. The development of technology or what is often called the digital era today will certainly affect all aspects of human life, including in the field of education. The impact of the advancement of information technology in the field of education is very large, such as causing addiction, especially if playing games, it can result in children behaving aggressively, experiencing impaired concentration, truant, easy emotions, and decreased performance. Students like to leave the study hours or not do the assignments given by the teacher because they are busy with social media and playing games. 
In addition, the advancement of information technology also results in reduced interaction between humans, children become lazy in socializing with their surrounding environment, even unwilling to go to school and undisciplined. They have made gadget and internet as their main needs. Even, they ignore humanitarian relationships and social care, including relationships in the family. Thus, it is clear that the development of information technology has changed behavior, attitudes, human actions, and can even affect human ethics, including student ethics towards teachers at school. Student ethics towards teachers needs attention in this digital era. Moreover, coupled with the results of a survey from the Indonesian Internet Service Providers Association (APJII), the majority of internet users in 2017 were in the age range of 13-18 years, this means that most internet users are school children [1].

Therefore, in this digital era, it is necessary to instill ethics with children in using digital media. The role of parents and teachers is very important in instilling ethics with children by providing education about the negative impacts of the internet and providing direction for using a healthy internet. In addition, families and schools must cooperate by making strict rules for children to use the internet and must also be able to set a good example in using the internet.

To instill the ethics of students in school, the role of the teacher is needed to be active by emphasizing the importance of the aspects of behavior, then there will be habituation and ethical training in learning activities. Furthermore, students are sought to be able to internalize ethics in the learning process. However, it would be better if in instilling ethics students refer to the thoughts of previous figures that have great attention in education, especially those related to student ethics. One of the Islamic leaders who contributed his thoughts to the importance of a student having ethics in carrying out the learning process was Hasyim Asy'ari.

Hasyim Asy'ari is a scholar who contributes ideas that direct students in carrying out their learning activities in order to achieve the goal of Islamic education, which creates a generation of Muslims who have the knowledge and expertise based on Islamic ethical values. Therefore, this article was written to discuss students' ethics towards teachers in the implementation of the learning process in the digital era, with reference to the educational thinking of Hasyim Asy'ari.

\section{Discussion}

\subsection{Educational thinking of Hasyim Asy'ari on Student Ethics towards Teachers}

Thought is an activity carried out by humans almost every time. Thought can be understood as anything that applies in the center of consciousness that arouses thoughts, feelings of ideas, and perceptions, and stores knowledge and memories. Critical thinking will bring many simple meanings such as very deep, detailed, observing and so on. Thought is also intended as an in-depth and critical understanding to improve understanding. Thought can help humans analyze statements carefully and look for legitimate evidence before making a decision.

Understanding of the notion of critical thinking must be viewed from various perspectives. This is because; the understanding of critical thinking is actually very broad and deep. Everyone can give an understanding of critical thinking based on experiences and studies carried out. In this study what is meant by thinking is a work, an idea, or an idea from someone who is expressed through oral and written. Someone in question is educational thought Hasyim Asy'ari. According to Hasyim Asy'ari education is very important, and he revealed that there are at least two qualifications in education. First, the importance of education is to maintain the title of the most noble being attached to that human being. This can be seen in his descriptions of the virtues and heights of the degree of knowledge of people, even when compared to worship experts. 
Second, the urgency of education lies in its contribution in creating a cultured and ethical society. The formulation appears in the description of the purpose of studying science, namely solely for practice [2]. The practice of a science means that someone who is knowledgeable is required to translate it into polite social behavior, so that it will create an ethical society order. The ethical community referred to here is students to the teacher.

Ethics of a student to the teacher, according to what was said by Hasyim Asy'ari should pay attention to the ten main ethics, namely:

1. Should always pay attention and listen to what is explained or said by the teacher.

2. Choosing a teacher who is wara 'means someone who is always careful in acting in addition to professionalism.

3. Following in the footsteps of a good teacher.

4. Be patient with teacher violence.

5. Visit the teacher in his place or ask permission first if you have to force the situation is not the place.

6. Sit neatly and politely when dealing with the teacher.

7. Speak politely and meekly.

8. Listen to all the fatwa.

9. Never interrupt when explaining.

10. Use the right member when giving something to him [3].

Hasyim Asy'ari's thinking is in line with the thoughts of his predecessor, Ibn Jama'ah, he said that busy in practicing a science because Allah is more important than carrying out sunnah worship activities in the form of prayer, fasting, prayer beads and so on. Because the benefits of knowledge are evenly distributed to their owners and other human beings, while the worship of the sunnah is limited to their owners [3].

So, if we look at the thinking and urgency of education offered by Hasyim Asy'ari in accordance with Law No. 20 of 2003 concerning National Education System article 3 which reads "National education functions to develop capabilities and form dignified national character and civilization in order to educate the nation's life, aiming at developing potential students to become faithful and devoted to God Almighty, noble, healthy, knowledgeable, capable, creative, independent, and a democratic and responsible citizen." Thus, the educational thinking of Hasyim Asy'ari is relevant to the goals of national education which together are to develop the potential of students to be noble.

The pattern of exposure to the concept of Hasyim Asy'ari education contained in the book Adab al-'Alim wa al-Muta'allim follows inductive logic, in which he begins his explanation by quoting verses from the Qur'an, hadiths, opinions of the scholars and poetry- poetry of wisdom. In that way, as if Hasyim Asy'ari provided the reader with the convenience of capturing the meaning in writing without having to explain it in his own language.

It also appears that Hasyim Asy'ari paid considerable attention to the teacher. The affirmation of the existence of a teacher who occupies a high position proves that the person concerned is very concerned with science and teaching. Hasyim Asy'ari explained the high status of claimants of science (students) and teachers by presenting the argument that God will raise the degree of people who believe and have knowledge.

Based on the description above, it can be explained that the educational thinking of Hasyim Asyari directed that humans can maintain the title of the noblest beings. In addition, it is also to create a cultured and ethical society. So, every knowledgeable human being is required to behave politely in society, so as to create an ethical society order. 


\subsection{Student Ethics towards Teachers in the Digital Age and their Relevance to Educational Thinking Hasyim Asy'ari}

Hasyim Asyari said that students in pursuing knowledge must have a holy intention to study, never intend for things that are worldly in nature and do not abuse or underestimate them. This opinion, if associated with the digital age, is of course different, if it is observed by students now most schools are not with pure intentions, but because they join friends, are directed by parents, consider the cost of education, distance from the location of education, get scholarships, claim linearity, job demands, and so on. For the purpose of taking education it is also different, if in the view of Hasyim Asy'ari the study must intend to get the pleasure of Allah, in the digital era it requires knowledge to get decent jobs and income, to help parents, to make parents proud, improve social status, so as not to be underestimated, and so on.

Furthermore, the views of Hasyim Asy'ari about not harassing and underestimating the study are also different, in the digital era there are students who underestimate the lessons given by the teacher, even harassing the teacher, there are those who do not want to go to class, hang out in the canteen, and even skip and fun playing games outside of school. Even in some regions in Indonesia there were those who injured their teacher and some reported their teacher to the police. Whereas in Islamic education it is clearly stated that one prejudice is only to your teacher, so Allah forbidden all blessings that your teacher has on you.

The description above illustrates the ethics of students in demanding knowledge from the point of view of Hasyim Asy'ari and the reality of the behavior of students in today's digital era. This means that in terms of studying most students in the digital age have not carried out their obligations as students to study seriously, they are more engrossed in their world, namely playing with friends, playing gadged and the internet. Even though this is the reality, there are still students who really learn seriously, excel and are able to compete at national and international levels.

While in terms of student ethics towards the teacher, Hasyim Asy'ari suggested ten main ethics, namely:

1. Should always pay attention and listen to what is explained or said by the teacher.

The first Hasyim Asy'ari thinking was also carried out by students in the current digital era, but in different ways and conditions, there are those who pay attention and listen carefully and very seriously, then give a positive response, until a mutual relationship occurs. On the other hand there are also those who just pay attention, look not enthusiastic, there are those who are driving, not active, and given the opportunity to ask questions, but no one asks, evaluated with questions and exam questions cannot be answered.

2. Choosing a teacher who is wara 'means someone who is always careful in acting in addition to professionalism.

For this second thought not all students can do it, because indeed the education system in the school is different from the pesantren. There is formal, informal, and informal education. In formal education institutions the teacher has been determined and written in the learning schedule, so students only follow and study seriously. For informal and non-formal education can choose the desired teacher. For the digital era, students do not choose teachers, but students choose good educational institutions.

3. Following in the footsteps of a good teacher.

All teachers should be good examples so that all students follow. However, not everything that teachers do can be followed by students, depending on the abilities of each student.

4. Be patient with teacher violence. 
In the digital era, there seems to be no hard teacher, even if there are still hard teachers, most students in the digital age cannot be patient, some are opposed, some report to the principal, parents, even report the police.

5. Visit the teacher in his place or ask permission first if you have to force the situation is not the place.

It is better to visit the teacher's house or to the house. Anyone must see the right time, not busy, not when worshiping, but see leisure time or if you urge permission first.

6. Sit neatly and politely when dealing with the teacher.

Actually the student seat is always neat, but sometimes after finishing learning the seat has changed, shifted, moved and so on. This must be embedded in students to always tidy up their seats both before and after the learning process takes place.

7. Speak politely and meekly.

As a student who is studying, certainly has a standard of success. The standard here is not just the amount of knowledge that has been mastered, but speaking politely and gently to anyone can also be used as a standard of success in studying. As in the proverb "rice is getting older, getting ducking", meaning that the more knowledge gained must be more polite in speaking and behaving.

8. Listen to all the policy.

Listening to the direction and advice of the teacher has become the responsibility of every student and all instructions, guidance, explanations, and advice should be followed by students, to achieve the common good.

9. Never interrupt when explaining.

At this point it becomes a clear measure of student ethics, if there are students who interrupt the teacher's explanation that means having bad ethics. Unless indeed the teacher concerned gives an opportunity to interrupt.

10. Use the right member when giving something to him.

In this last point, everyone is used to it. What needs to be done is to continue to have good ethics with anyone.

The ten student ethics towards the teacher proposed by Hasyim Asy'ari are very well applied in this every learning of digital era, so that all students in this country have good ethics towards their teachers. This is in line with the goal of national education, which is to form a dignified character and national civilization in order to educate the nation's life, aiming at developing potential students to become human beings who believe and fear God Almighty, noble, healthy, knowledgeable, capable, creative , be independent, and become a democratic and responsible citizen.

Hasyim Asy'ari's educational thinking about student ethics towards teachers is very relevant to the current digital era, because his thoughts are written by taking into account the very rapid changes in the field of education that occur in those countries. This was conveyed by [4] that "Hasyim Asy'ari wrote the book Adab al-'alim wa al-Muta'allim driven by the situation of education which experienced rapid changes, from the traditional system (pesantren) to the modern education system due to the system education applied by the Netherlands." It means that even though this thought of Hasyim Asy'ari has been long, it remains relevant if applied in the current digital era. However, there are still differences in how to implement it.

Teachers in the digital era certainly cannot force students to follow the old model which is not in line with the times. This is in accordance with the words that were once uttered by a friend Ali Bin Abi Thalib "Educate your child according to his day, because he lives not in your age". Teachers who educate students in the digital era must be creative and innovative. Teachers as the main actors of education must follow the times, because the pattern of education is 
meaningless without the support of the perpetrators. One of the ways that teachers can educate students in the digital era is by utilizing information technology advances in the learning process.

Utilizing the advancement of information technology in the learning process will bring the teacher closer to students. This can be done by utilizing gadged for education by utilizing social media such as facebook, whatssap, instagram and so on. Teachers can create social media, such as class groups, extracurricular groups, or other guiding groups that can be used to interact with students. Social media can be a solution to the limitations of space and time between teachers and students.

However, keep in mind the closeness between teachers and students must still have limits. That is, even though the teacher must establish closeness with students in the digital era, the teacher may not lose his authority. The teacher must maintain his dignity, both in the real world and in the virtual world. Being close to students does not mean that teachers or students are free to do anything. There are still rules that limit; there are ethics that must be upheld. If the teacher is able to place himself, he will undoubtedly be able to guide students to become students of the present age who are not soluble in the euphoria of technological progress. By instilling ethics education, it is hoped that it can form a quality and ethical young generation that will bring Indonesia even better.

\section{Conclusion}

Educational thinking Hasyim Asya'ri emphasized the importance of students to purify their souls in learning, because with a clean soul, a student will be able to focus and be serious in his learning, which further strengthens their motivation in learning. While it relates to the ethics of a student towards his teacher, Hasyim Asy'ari emphasizes high respect for the teacher, considering that the teacher is someone who has contributed to directing and guiding in studying.

Hasyim Asy'ari's educational thinking basically directed humans to be able to maintain the title of the noblest creature. In addition, it is also to create a cultured and ethical society. So, every knowledgeable human being is required to behave politely in society, so as to create an ethical society order. There are ten student ethics towards the teacher which was stated by Hasyim Asy'ari. These ten ethics are very well applied in this every learning of digital era, so that all students in this country have good ethics towards their teachers. This is in line with one of the goals of national education, which is forming noble students.

In the context of classroom learning, one of the ways that teachers can educate students in the digital era is to utilize the advances in information technology in the learning process, namely by utilizing social media to create class groups, extracurricular groups, and other mentoring groups that can be used to interact and convey information, related subject matter, and internalize noble values, so that students have good ethics.

\section{References}

[1] Asosiasi Penyelenggara Jasa Internet Indonesia, 'Hasil Survei Penetrasi dan perilaku Pengguna Internet Indonesia 2017', 2019.

[2] M. H. Asy'ari, Adabul 'Alimwa Al-Muta'allim. Jombang: Maktabah Turats Al-Islamy, 1415.

[3] S. Rizal, Filsafat Pendidikan Islam. Jakarta: Ciputat Pers, 2002. 
[4] Sya'roni, Model Relasi Ideal Guru dan Murid. Yogyakarta: Teras, 2007. 